Brooks, M. E. \& Eprs, H. B. G. (1958). J. gen. Microbiol. 21, 144-155

\title{
Taxonomic Studies of the Genus Clostridium: Clostridium bifermentans and C. sordellii
}

\author{
BY M. ELIZABETH BROOKS AND H. B. G. EPPS \\ Wellcome Research Laboratories, Beckenham, Kent
}

\begin{abstract}
SUMMARY: In an attempt to elucidate the taxonomic relationship of Clostridium bifermentans and C. sordellii about sixty strains assigned to one or other of the two species were examined. Two groups of strains differing in their cultural and biochemical properties were recognized. One closely resembled the type culture of C. bifermentans (Tissier \& Martelly, 1902), and the other, in which some strains were pathogenic, resembled the $C$. sordellii isolate ' 82 ' of Sordelli. The former of these groups is clearly to be regarded as $C$. bifermentans and the latter as $C$. sordellii. It has been shown that the two species, although similar in many respects, are distinct and easily distinguishable. In view of this, the present practice of some bacteriologists of combining the two species under the name $C$. bifermentans is incorrect and should be discontinued.
\end{abstract}

Although Clostridium bifermentans was first isolated by Tissier \& Martelly in 1902, and $C$. sordellii by Sordelli in 1922, the taxonomic relationship of these two organisms is still the subject of controversy. The use of either of two criteria (cultural and biochemical character or pathogenicity) for the separation of $C$. bifermentans and C. sordellii, together with the failure of many American and British bacteriologists to recognize their existence as separate species, has given rise to much confusion. In the English-language literature most authors combine the two species under the name $C$. bifermentans (noting the existence of $C$. sordellii as a pathogenic variety) and quote a description including features of the two organisms only some of which are common to both. Most French workers recognize the existence of the two species, mainly on serological grounds, but the evidence they present is based on the examination of very few $C$. sordellii strains.

To confuse the matter further, each species has been described under at least three names. The original isolate of Clostridium bifermentans was named Bacillus bifermentans sporogenes (Tissier \& Martelly, 1902) and later re-named B. bifermentans (Weinberg \& Séguin, 1918), in accordance with the principle of binominal nomenclature. In $1922 \mathrm{Hall}$ examined a number of alleged $B$. bifermentans strains and found some to be non-motile (as in the original description) and others to be motile; for the latter he proposed the creation of a new species, $\boldsymbol{B}$. centrosporogenes. Consequent on the demonstration of motility in young cultures of $B$. bifermentans (Levenson, 1936), the two species were recombined (McCoy \& McClung, 1936; Clark \& Hall, 1937). C. sordellii was originally named $\boldsymbol{B}$. oedematis sporogenes (Sordelli, 1922), and was renamed $\boldsymbol{B}$. sordellii by Hall \& Scott in 1927. In the same year Meleney, Humphreys \& Carp (1927) isolated an anaerobic bacillus which they considered to be a new species and named $B$. oedematoides, and which was later shown to be 
identical with $B$. sordellii (Humphreys \& Meleney, 1927-8; Hall \& Scott, 1931).

The first suggestion that Clostridium bifermentans and $C$. sordellii might be regarded as one species appears to have been made by Stewart (1938) on cultural and serological grounds, although in 1937 Clark \& Hall had already demonstrated cross-agglutination between the two species, and noted the ability of $C$. bifermentans antisera to confer some protection against challenge with C. sordellii. The latter authors, however, considered that C. sordellii merited species status because of its marked pathogenicity. Lillie (footnote, 1938) referred to the work of Clark \& Hall and of Stewart, but did not think that the two species had been fully established as identical. Since Stewart's paper of 1938, the concept of C. bifermentans and C. sordellii as a single species seems to have been generally accepted by British and American workers, including Smith (1955), and the authors of the relevant sections of Bergey's Manual (1957), Topley and Wilson's Principles (1955) and Reed (1952). However, Sterne \& van Heyningen, in Bacterial and Mycotic Infections of Man (1958), considered C. bifermentans and $C$. sordellii to be distinct, but not necessarily worthy of separate species status. Prévot (1938), in a taxonomic study of the genus Clostridium, described C. bifermentans and $C$. sordellii under separate headings. Later, Prévot \& Cordier (1941) studied the metabolism of the two species, and, although they found them to be virtually identical in this respect, considered that the pathogenicity of C. sordellii justified its species status. In 1952 Huet \& Aladame, using the urease test of Roland, Bourbon \& Szturm (1947), noted the production of urease by $C$. sordellii. Tardieux \& Nisman (1952), as a result of serological studies of extracts of $C$. bifermentans and $C$. sordellii cultures, concluded that the species were distinct although immunologically closely related. Tataki \& Huet (1953) examined a number of C. bifermentans and two C. sordellii strains serologically and for urease production. They were able to distinguish two serological groups, one comprising all the urease-positive strains including some which had been assigned to $C$. bifermentans (presumably on the grounds of non-pathogenicity), and the other consisting of the urease-negative C. bifermentans, together with two strains of the latter species in which the urease reaction was doubtful. They concluded that all the urease-positive strains, including those lacking pathogenicity, should be regarded as $C$. sordellii. This concept of $C$. sordellii and $C$. bifermentans as two distinct species, the former characterized by urease production and variable as regards pathogenicity, and the latter non-urease producing and non-pathogenic, is upheld by Prévot (1955). Prévot (1957) described C. sordellii as rods, 3.0-5.0 $\mu$ by $1 \cdot 2-$ 1.5 $\mu$; motile; forming arborescent colonies in deep agar; fermenting glucose, fructose, and maltose, but not glycerol or sorbitol; pathogenic; highly toxigenic; and producing urease. C. bifermentans was described as rods, 5.0-6.0 $\mu$ by $0 \cdot 8-1 \cdot 0 \mu$; motile; forming clustered lenticular or raspberry-like colonies in deep agar; fermenting glucose, fructose, maltose, glycerol and sorbitol; non-pathogenic; non-toxigenic; and non-urease producing. Prévot also stated that $C$. sordellii was more strongly proteolytic than $C$. bifermentans 
although protein metabolism followed the same pattern in both species; that neither species produced nitrites from nitrates; and that some strains from each were haemolytic and produced lecithinase. Recently Meisel \& Rymkiewicz (1958), investigating the antigenic properties of spores of proteolytic clostridia, found no trace of cross-agglutination between $C$. sordellii and C. bifermentans spore suspensions and spore-antisera.

The investigations reported below were undertaken to elucidate the relationship of Clostridium sordellii and C. bifermentans in the course of general taxonomic study of the genus Clostridium (as defined in Bergey's Manual, 1957).

\section{METHODS}

\section{Strains examined}

Sixty-two cultures obtained from various sources were studied. To simplify the tabulation and discussion of results the strains will be grouped under three headings:

Clostridium bifermentans: those strains which are non-pathogenic and nonurease producing, resembling the type strain (Tissier \& Martelly). Twentyfour strains were examined; National Collection of Type Cultures, nos. 1341, 506 and 6928; Wellcome Research Laboratories Collection, nos. 1617, 2086, 1622, 1625, 1626 and 1628; Institut Pasteur, Paris, Collection, 'TM'; L. DS. Smith's Collection, nos. B-5, B-11, B-13, B-14, B-26, B-27, S-6479, S-7172 and U-VRL; and five strains isolated at the Wellcome Research Laboratories, 'Bif. 1, 2 and 3' from soil, 'OWM 2 ' from pathological material received from Khartoum, and ' $10015 \mathrm{R}$ ' from a contaminated culture of $C$. multifermentans.

Clostridium sordellii $(\mathbf{P})$ : those strains which are pathogenic and produce urease. Thirteen strains were examined; National Collection of Type Cultures, nos. 8780 and 2919; Wellcome Research Laboratories Collection, nos. 1732, 1733, 1734 and 1694; L. DS. Smith's Collection, no. S.-15; Mr J. Hepple's Collection, ' $492 \mathrm{E}$ '; and five strains isolated at the Wellcome Research Laboratories, nos. $646 \mathrm{~L}$ and $650 \mathrm{~L}$ from contaminated cultures of $C$. sphenoides, ' $46 / 296$ ' from a culture received from Iran, and nos. 83050 and $T$ isolated from a dead heifer.

Clostridium sordellii (N-P); those strains which produce urease but are non-pathogenic. Twenty-five strains were examined; National Collection of Type Cultures, nos. 1340, 6927, 6801, 6800, 2914, 6929, 6799 and 6801 (opaque variant); Wellcome Research Laboratories Collection, nos. 1619, 1620, 1621, 1623, 1624, 1627 and 3936; L.DS. Smith's Collection, nos. S-7048E, S-7166, S-7363, S-8841, S-8853 and B-AA5; Mr J. Hepple's Collection, nos. 484 E and $512 \mathrm{E}$; and two strains ' 9831 ' and ' 9833 ' isolated from pathological material at the Wellcome Research Laboratories.

\section{Fermentation reactions}

Media. Fermentation of carbohydrates was examined in a peptone water medium containing the carbohydrate under test at $1.0 \%(\mathrm{w} / \mathrm{v})$ concentration, and $0.2 \%(\mathrm{v} / \mathrm{v})$ of a $6.0 \%(\mathrm{w} / \mathrm{v})$ solution of bromocresol purple. The medium 
was dispensed in $\frac{1}{4}$ oz. screw-cap bottles, and iron strip added to promote reducing conditions. The carbohydrates used for the tests were arabinose, rhamnose, xylose, glucose, fructose, galactose and mannose; lactose, sucrose, maltose and trehalose; raffinose, inulin, dextrin, glycogen and starch; glycerol, adonitol, mannitol, sorbitol, dulcitol and inositol; salicin and aesculin.

Inoculation and incubation. The peptone water sugars were inoculated with 24 or $48 \mathrm{hr}$. Robertson's meat broth cultures, and incubated at $37^{\circ}$ for 2 weeks.

Method of testing. Cultures were examined for the production of acid and gas, Universal Indicator (British Drug Houses Ltd., Poole) being added where the bromocresol purple had been decolorized. The $\mathrm{pH}$ value of cultures in aesculin peptone water were checked potentiometrically, and a reading of less than $\mathrm{pH} 6.5$ was recorded as positive for acid production.

\section{Proteolytic reactions}

To demonstrate proteolytic activity strains were grown in media containing, respectively, gelatin, casein, coagulated serum, azocoll (Oakley, Warrack \& van Heyningen, 1946), meat particles and coagulated egg albumin.

Titration of gelatinase activity. The substrate used was a $10 \%(\mathrm{w} / \mathrm{v})$ solution of gelatin in distilled water, with the addition of Congo red, and $0.5 \%$ phenol as preservative. The reagent was stored in the cold and melted by warming to about $40^{\circ}$ immediately before use.

Doubling dilutions of samples of $48 \mathrm{hr}$. cultures were added in $1.0 \mathrm{ml}$. amounts to $1.0 \mathrm{ml}$. of the gelatinase reagent. After thorough mixing, as shown by the even distribution of the Congo Red colour, the mixtures were incubated at $37^{\circ}$ for $18 \mathrm{hr}$., then placed at $4^{\circ}$ for $1 \mathrm{hr}$., and the results read at this temperature.

\section{Chromatographic examination of Clostridium bifermentans and}

\section{C. sordellii cultures}

Twenty-five ml. volumes of the chromatographic medium of Woiwod \& Proom (1950) and of Robertson's meat broth were used for this study. Both broth and agar surface cultures were used as inocula. Incubation was at $37^{\circ}$ (in an anaerobic jar in the case of the chromatographic medium) and the cultures were tested after 1,3 and 7 days.

The solvent used for chromatography was butanol + acetic acid, and the chromatograms were sprayed with ninhydrin for general examination, and with Pauley's diazo reagent for histidine and related compounds.

\section{Urease production}

Cultures were grown for 24 and $48 \mathrm{hr}$. at $37^{\circ}$ in $20 \mathrm{ml}$. amounts of Robertson's meat broth. A few strains from each group were also grown in $100 \mathrm{ml}$. amounts of a similar medium and tested daily for 4 days.

The reagent used was a slightly modified version of that of Roland, Bourbon \& Szturm (1947) and Huet \& Aladame (1952), and was made up as follows: $0 \cdot 1$ g. $\mathrm{KH}_{2} \mathrm{PO}_{4} ; 0.1$ g. $\mathrm{K}_{2} \mathrm{HPO}_{4} ; 0.5$ g. $\mathrm{NaCl} ; 2.0$ g. urea; $1.0 \mathrm{ml} .95 \%(\mathrm{v} / \mathrm{v})$ 
ethanol in water; $100 \mathrm{ml}$. distilled water; $5.0 \mathrm{ml}$. Universal Indicator; sufficient $0 \cdot 1 \mathrm{~N}-\mathrm{HCl}$ to give an orange colour (about $\mathrm{pH} 6 \cdot 0$ ).

A $2.5 \mathrm{ml}$. sample of the culture under test was transferred to a test tube $(80 \mathrm{~mm} . \times 8.0 \mathrm{~mm}$.) and centrifuged. The supernatant fluid was discarded and the sediment washed once in $1.0 \%(\mathrm{w} / \mathrm{v})$ saline and finally resuspended in $1.0 \mathrm{ml}$. distilled water. One $\mathrm{ml}$. of urease reagent was added and, after thorough mixing, the test was incubated at $37^{\circ}$.

\section{Various biochemical reactions}

Indole production. Twenty-four- and 48-hr. cultures in Robertson's meat broth were examined for indole production by means of Ehrlich's reagent and by the vanillin test (Spray, 1936).

Bromocresol purple milk. Cultures were incubated at $37^{\circ}$ for 1-14 days.

Nitrite production. All strains were grown in nitrite-free broth containing potassium nitrate and incubated at $37^{\circ}$ for 2-3 days. Cultures were examined for the presence of nitrites by means of sulphanilic acid and diphenylamine in acetic acid.

Voges-Proskauer and Methyl Red tests. All strains were grown for 24 and $48 \mathrm{hr}$. in glucose phosphate broth, and tested for the production of acetylmethylcarbinol by O'Meara's modification of the Voges-Proskauer test, and for acid production by the addition of methyl red.

\section{Toxin production and pathogenicity}

Lecithovitellin plates. All strains were grown on agar plates containing lecithovitellin (Macfarlane, Oakley \& Anderson, 1941) with or without the addition of Clostridium welchii $\alpha$-antiserum. Incubation was in anaerobic jars at $37^{\circ}$ for $24 \mathrm{hr}$.

Blood agar plates. All strains were grown on horse-blood agar plates incubated in anaerobic jars at $37^{\circ}$ for $24 \mathrm{hr}$.

Haemolysin and lecithinase production in broth cultures. All strains were examined after growth for 6 and $24 \mathrm{hr}$. in $100 \mathrm{ml}$. volumes of broth containing meat particles. Thiomersalate at $0.01 \%(\mathrm{w} / \mathrm{v})$ concentration was added to all cultures before testing.

Buffer solutions. The buffer solutions used were saline containing $\mathrm{CaCl}_{2}$ and gelatin ('cagsaline'), cagsaline with the addition of Clostridium welchii antiserum to give a final concentration of $5.0 \propto$ units/ml., borate buffer saline, 'phosthio' buffer (see below) and sodium acetate buffer.

'Cagsaline' (modified from Oakley \& Warrack, 1941): add $138.75 \mathrm{ml}$. of $2.0 \%(\mathrm{w} / \mathrm{v})$ calcium chloride solution to $100 \mathrm{ml}$. of $5.0 \%(\mathrm{w} / \mathrm{v})$ gelatin solution and $22.5 \mathrm{~g}$. sodium chloride; make up to $2.5 \mathrm{l}$. with distilled water, add $0.2 \mathrm{~g}$. thiomersalate and $2.5 \mathrm{~g}$. phenol, fill out and autoclave at $10 \mathrm{lb} . / \mathrm{sq}$.in. for 10 min.; keep in cold.

Borate buffer saline (modified from Glenny, Pope \& Waddington, 1928): dissolve $30 \mathrm{~g}$. of a mixture of $59 \mathrm{~g}$. borax $+84 \mathrm{~g}$. boric acid $+99 \mathrm{~g}$. sodium chloride in $21.0 \cdot 3 \%(\mathrm{w} / \mathrm{v})$ sodium chloride solution.

'Phosthio' buffer (Oakley, Warrack \& Clarke, 1947): to $4.0 \mathrm{ml}$. distilled 
water add $0.1 \mathrm{ml}$. thiolacetic acid, adjust $\mathrm{pH}$ to 6.5 with $\mathrm{N}-\mathrm{NaOH}$, and make up to $25 \mathrm{ml}$. with $\mathrm{M} / 5$ phosphate buffer (pH 6.5).

Sodium acetate buffer (Oakley, Warrack \& Clarke, 1947): to 27.2 g. sodium acetate in 11 . distilled water add $50 \mathrm{ml}$. of $5.0 \%(\mathrm{v} / \mathrm{v})$ acetic acid in $1.0 \%$ saline.

Procedure. One ml. of culture was added to $0.5 \mathrm{ml}$. of each of the five buffers; these mixtures were made up in triplicate. To one set of mixtures was added $0.5 \mathrm{ml}$. of a 1/10 suspension of sheep red blood cells, to another $0.5 \mathrm{ml}$. of a 1/10 suspension of horse red blood cells, and to the third $0.5 \mathrm{ml}$. of lecithovitellin (a suspension of egg-yolk in saline). After thorough mixing all tests were incubated in a water bath at $37^{\circ}$ for $2 \mathrm{hr}$. and then left at room temperature for $16 \mathrm{hr}$. after which the results were read.

\section{Animal tests}

Media and incubation. All strains were inoculated into $100 \mathrm{ml}$. amounts of broth containing meat particles and incubated at $37^{\circ}$ for $24 \mathrm{hr}$. Some strains from each group were also tested after incubation for $6 \mathrm{hr}$. Thiomersalate to $0.01 \%(\mathrm{w} / \mathrm{v})$ final concentration was added to all filtrates and supernatant fluids, but not to cell suspensions.

Intravenous injections. Culture filtrates were injected intravenously into mice in $0.5 \mathrm{ml}$. amounts. Strains which failed to kill were retested using supernatant fluids from centrifuged cultures. Filtrates and supernatant fluids were injected very slowly since both contained some factor which caused profound shock or death on rapid intravenous injections.

Intradermal injections. Culture filtrates, undiluted and diluted $1 / 5$ and $1 / 25$ in broth were injected intradermally into guinea-pigs in $0.25 \mathrm{ml}$. amounts. The results of the injections were read after 1 and 2 days.

Intramuscular injection. Suspensions of twice-washed bacteria in $1.0 \%$ saline containing $0.5 \%(\mathrm{w} / \mathrm{v})$ calcium chloride were injected into the hind legs of mice in $0.5 \mathrm{ml}$. amounts. All dead mice were examined for the characteristic signs of Clostridium sordellii infection.

\section{Morphology of colonies and bacteria}

Morphology of colonies. All strains were grown on horse-blood agar plates containing $1 \cdot 8 \%(\mathrm{w} / \mathrm{v}$; normal) and $3.0 \%(\mathrm{w} / \mathrm{v}$; stiff) New Zealand agar, and containing $5.0 \%(\mathrm{v} / \mathrm{v})$ horse blood. Inoculated plates were incubated in anaerobic jars for 24 and $48 \mathrm{hr}$.

Morphology of bacteria. Twenty-four- and 48-hr. agar surface and broth cultures were examined. Measurements of the size of the bacteria were made on heat-fixed Gram-stained films using a grid eye-piece. Films stained by Giemsa's, Muir's, and the Alcian-blue + carbol fuchsin and phosphomolybdic acid + methyl green methods were also examined. 


\section{RESULTS}

\section{Fermentation reactions}

The results of the fermentation tests are shown in Table 1. The fermentation of mannose, sorbitol and salicin clearly differentiated the Clostridium bifermentans strains from those of the two $C$. sordellii groups, although one $C$. bifermentans strain failed to fement sorbitol, and another salicin. Aesculin was fermented by only half of the C. bifermentans strains and was therefore less useful for differentiation. The present results are not wholly in agreement with many reported elsewhere. Many discrepancies are because some workers have regarded $C$. bifermentans and $C$. sordellii as a single species, and because others have used pathogenicity as the sole criterion for species separation, and thus including urease-positive strains in $C$. bifermentans. The production of acid and gas from glycerol by all but two of the $C$. sordellii strains (those which produced gas only) was contrary to the observations of Prévot and of several other workers; no explanation can be suggested for this discrepancy.

Table 1. Results of fermentation tests

\begin{tabular}{|c|c|c|c|c|c|c|c|c|c|c|}
\hline \multirow[b]{2}{*}{ Group } & \multirow[b]{2}{*}{$\begin{array}{l}\text { No. of } \\
\text { strains } \\
\text { ex- } \\
\text { amined }\end{array}$} & \multicolumn{9}{|c|}{ No. of strains fermenting } \\
\hline & & 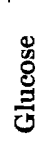 & 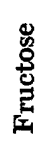 & 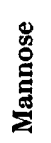 & 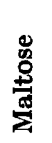 & 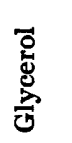 & $\begin{array}{l}\overrightarrow{0} \\
\stackrel{+}{0} \\
\stackrel{0}{\circ} \\
\text { n }\end{array}$ & 疍 & 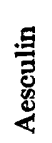 & 苞总 \\
\hline C. bifermentans & 24 & 24 & 24 & 24 & 24 & 24 & 23 & 23 & 16 & 0 \\
\hline C. sordellii (P) & 13 & 13 & 13 & 0 & 13 & 13 & $\mathbf{0}$ & 0 & 0 & 0 \\
\hline C. sordellii (N-P) & 25 & 25 & 25 & $\mathbf{0}$ & 25 & $25^{*}$ & $\mathbf{0}$ & $\mathbf{0}$ & $\mathbf{0}$ & 0 \\
\hline
\end{tabular}

* Two strains repeatedly produced abundant gas but no acid in glycerol-peptone water.

\section{Proteolytic reactions}

All strains digested casein, coagulated serum, azocoll, meat particles and, to a lesser extent, coagulated egg albumin which was blackened by all strains but only completely digested by a few.

Gelatinase activity. All strains liquified gelatin and a rough quantitative measurement of gelatinase activity was made in an attempt to confirm Prévot's observation that Clostridum bifermentans produced less gelatinase than $C$. sordellii. The results are shown in Table 2. The results obtained did not suggest a constant difference between the three groups in respect of gelatinase activity, although the Clostridum bifermentans strains tended to produce the most gelatinase. However, this group showed the widest variation in gelatinase production and included some of the least active strains.

\section{Chromatographic examination of cultures}

Grown in chromatographic medium. No consistent difference between the groups was seen. This agreed with the findings of Prévot \& Cordier (1941).

Grown in Robertson's meat broth. Paper chromatography revealed distinct 
and consistent differences between the Clostridium bifermentans and the C. sordellii cultures. The most obvious difference was the absence of histidine from the $C$. bifermentans cultures and its presence in large amounts in both pathogenic and non-pathogenic $C$. sordellii.

Table 2. Production of gelatinase by Clostridium bifermentans and C. sordellii strains. Results of gelatinase titrations

\begin{tabular}{|c|c|c|c|c|c|c|c|c|c|c|}
\hline \multirow[b]{2}{*}{ Group } & \multirow{2}{*}{$\begin{array}{c}\text { No. of } \\
\text { strains } \\
\text { ex- } \\
\text { amined }\end{array}$} & \multicolumn{9}{|c|}{ No. of strains positive at dilution } \\
\hline & & $1 / 1$ & $1 / 2$ & $1 / 4$ & $1 / 8$ & $1 / 16$ & $1 / 32$ & $1 / 64$ & $1 / 128$ & $1 / 256$ \\
\hline C. bifermentans & 24 & 23 & 22 & 19 & 18 & 16 & 13 & 10 & $\mathbf{3}$ & $\mathbf{0}$ \\
\hline C. sordellii (P) & 13 & 13 & 13 & 12 & 6 & $\mathbf{0}$ & $\mathbf{0}$ & $\mathbf{0}$ & $\mathbf{0}$ & $\mathbf{0}$ \\
\hline C. sordellii $(\mathrm{N}-\mathrm{P})$ & 25 & 23 & 19 & 12 & 4 & $\mathbf{0}$ & $\mathbf{0}$ & $\mathbf{0}$ & $\mathbf{0}$ & $\mathbf{0}$ \\
\hline
\end{tabular}

Urease production

The speed at which positive reactions developed varied with the amount of urease produced. All the urease-producing strains gave positive results within 4-5 hr., although the strength of the reactions increased up to $48 \mathrm{hr}$., with colour changes through yellow-green, green and blue-green to blue in strongly positive strains. Tests negative at $5 \mathrm{hr}$. were still negative at $72 \mathrm{hr}$. All strains gave unequivocal results which were consistently reproducible; replicate cultures of any strain gave virtually the same final colour. In the urease positive strains (by definition Clostridium sordellii) no correlation was observed between pathogenicity and the strength of the urease reaction. An unexpected observation made in the course of these tests was that many C. bifermentans strains had the ability to suppress the positive urease reactions when grown as mixed cultures with $C$. sordellii. This inhibition was confirmed on several occasions and might easily mask the presence of $C$. sordellii if the urease reaction were used as a 'diagnostic' test with a naturally occurring mixture of the two species. No inhibition was observed when washed sediments or supernatant fluids of $C$. bifermentans cultures were added to $C$. sordellii sediments immediately before testing. As indicated in Table 1, the subdivision of the bifermentans/sordellii complex on the basis of urease production agreed with subdivision based on fermentation reactions.

\section{Various biochemical reactions}

Indole production. All strains in each of the three groups produced indole, although six of the twenty-four strains of Clostridium bifermentans gave very weakly positive reactions. A number of strains in each group were also tested after growth for 8 days; all the $C$. bifermentans cultures gave negative, and the $C$. sordellii cultures positive reactions with Ehrlich's reagent and the vanillin test. None of the strains gave a vanillin violet reaction.

Bromocresol purple milk. All strains tested clotted and then digested the milk. The speed and extent of digestion of the clot, decolorization of the indicator and the amount of acid produced were variable but apparently uncorrelated with urease production. 
Nitrite production. All strains gave negative results when tested for nitrite.

Voges-Proskauer and Methyl red tests. No strain produced acetylmethylcarbinol. The results of the Methyl red test were variable: 18 of the 24 cultures of Clostridium bifermentans, 8 of the 13 cultures of $C$. sordellii $(\mathrm{P})$ and 19 of the 23 cultures of $C$. sordellii (N-P) gave positive results.

\section{Toxin production and pathogenicity}

Lecithovitellin plates. Most strains in each group produced weak to moderately strong precipitation, which was in all cases inhibited by the addition of Clostridium welchii $\alpha$-antiserum. No colonies were lustrous.

Blood agar plates. Most cultures of each of the three groups were haemolytic, although in some the degree of haemolysis was very slight and did not extend beyond the edges of the colonies. A few strains in each group were consistently non-haemolytic.

Haemolysin and lecithinase production in broth cultures. There was little or no difference between the groups in respect of the production of haemolysins and lecithinases. None of the Clostridium bifermentans strains haemolysed sheep cells in any of the buffers, but apart from this observation, which requires further investigation, the results generally confirmed the observations of Miles \& Miles (1947), Macfarlane (1948), Prévot \& Capponi (1949) and Prévot \& Malgras (1950) that some strains of each species produce haemolysins and lecithinases which are immunologically related to the $\alpha$-lecithinase of $C$. welchii. No differences between the three groups were observed.

Animaltests. None of the urease-negative cultures (Clostridium bifermentans) showed any lethal, dermonecrotic or pathogenic properties. Thirteen of the urease-positive strains $(C$. sordellii $(\mathrm{P}))$ were rapidly lethal on intravenous injection, elicited the production of characteristic $C$. sordellii skin lesions (central purple-brown necrotic area with surrounding and underlying massive oedema), and caused death within $18 \mathrm{hr}$. when injected intramuscularly. The remaining twenty-five urease-positive strains (C. sordellii $(\mathbf{N}-\mathbf{P})$ ) showed no lethal, demonecrotic or pathogenic activity, and were indistinguishable by animal tests from the urease-negative strains. The fact that strongly lecithinase-positive $6 \mathrm{hr}$. culture filtrates of C. bifermentans and C. sordellii (N-P) strains were non-toxic agreed with the observations of Miles \& Miles (1947) that the lecithinases of these species are considerably less toxic than the immunologically closely related $\alpha$-lecithinase of $C$. welchii.

\section{Morphology of colonies and bacteria}

Morphology of colonies. The colonies of Clostridium sordellii and C. bifermentans were frequently so dissimilar that it would have been possible to assign most strains to their correct species on appearance alone. On normal plates $(1 \cdot 8 \%(\mathrm{w} / \mathrm{v})$ New Zealand agar) even after thorough drying, the $C$. sordellii colonies tended to spread, forming a continuous film with a characteristic marbled pattern. On stiff plates $(3 \%(\mathrm{w} / \mathrm{v})$ New Zealand agar) they tended to form lozenge-shaped colonies, the long axes of which followed the direction of streaking. These colonies were greyish white, translucent in young cultures but 
became more opaque with the onset of spore formation, with crenate to coarsely rhizoidal margins, and peaked and ridged contours. The $C$. bifermentans strains formed opaque, white to yellowish, more or less circular, low convex or flattopped colonies with entire to slightly undulate margins. They showed no tendency to spread except on very wet normal agar plates. The differences between $C$. bifermentans and $C$. sordellii colonies are shown in Pl. 1.

Morphology of bacteria. No morphological differences between the bacteria of the three groups were observed. Rods of all strains were within the size range $c .0 \cdot 6-1 \cdot 0 \mu$ width by $2 \cdot 0-6 \cdot 0 \mu$ length, and all were strongly Grampositive. There was no difference between groups in respect of the occurrence, shape, position or size of spores, which were cylindrical to oval, central to subterminal, and did not noticeably swell the rods.

\section{DISCUSSION}

In the light of the investigations detailed above, and of the findings of other workers, particularly those reported in the Annales de I'Institut Pasteur, it is clear that two distinct groups, differing consistently in respect of a number of characters, exist within the bifermentans/sordellii complex. The only question, therefore, is whether these differences are sufficiently great to merit the raising of the groups to species status. The criteria for species separation within the Eubacteriales, particularly in the case of the pathogenic organisms, are somewhat variable. However, it is difficult to justify the inclusion within the same species of organisms differing in colony morphology, fermentation of carbohydrates, protein metabolism and urease production, especially when these differences are correlated with serological groupings (Tataki \& Huet, 1953; Tardieux \& Nisman, 1952; Meisel \& Rymkiewicz, 1958). The separation of Clostridium bifermentans from $C$. sordellii (using urease production and fermentation reactions as criteria) would therefore seem inevitable. The question then arises as to the validity of using pathogenicity for subdividing the strains assigned to $C$. sordellii. Pathogenicity, unsupported by other characteristics, is not a satisfactory criterion for species separation, since it is frequently lost, especially after repeated subcultivation. There are several known non-pathogenic subcultures derived from Sordelli's presumably originally pathogenic isolate ' 82 '. Thus there appears to be scant justification for granting separate species status to the pathogenic and non-pathogenic urease-positive strains, and the inclusion of both within C. sordellii (as suggested by Tataki \& Huet, 1953, and Prévot, 1955, 1957), would not prejudice further subdivision if future research showed this to be desirable.

We wish to thank Mr J. Hepple of Glaxo Laboratories, Professor A-R. Prévot (Institut Pasteur), Professor L. DS. Smith (Montana State College), and Dr S. T. Cowan, Curator of the National Collection of Type Cultures for some of the strains included in this survey. We would also like to thank our colleagues at the Wellcome Research Laboratories: Dr A. J. Woiwod and Mr R. Knight for the chromatographic examination of cultures; Mr E. A. Jones and Mr D. R. Adams for the photographs; Miss A. Shuard and Miss M. Green for technical assistance; Dr M. Sterne, for help and guidance throughout the survey and in the preparation of the manuscript. 


\section{REFERENCES}

Bergey's Manual of Determinative Bacteriology (1957), 7th ed. Eds. R. S. Breed, E. G. D. Murray \& N. R. Smith. London: Baillière, Tindall and Cox.

Clark, F. E. \& Hall, I. C. (1937). A comparative study of Bacillus bifermentans (Tissier and Martelly), Bacillus centrosporogenes (Hall) and certain closely related proteolytic anaerobes. J. Bact. 33, 23.

Glenny, A. T., Pope, C. G. \& Waddington, H. (1928). The stability of Schick toxin. J. Path. Bact. 31, 133.

HALL, I. C. (1922). Differentiation and identification of the sporulating anaerobes. J. infect. Dis. 30, 445.

Hall, I. C. \& ScotT, A. L. (1931). The serologic agglutination of Bacillus sordellii and Clostridium oedematoides. J. Bact. 22, 375.

HaLl, I. C. \& Scotт, J. P. (1927). Bacillus sordellii, a cause of malignant edema in man. J. infect. Dis. $41,329$.

Huet, M. \& Aladame, N. (1952). Recherches sur l'uréase des bactéries anaérobies. Ann. Inst. Pasteur, 82, 766.

Humphreys, F. \& Meneney, F. L. (1927-8). The identity of $\mathrm{Cl}$. oedematoides and B. sordellii. Proc. Soc. exp. Biol., N.Y. 25, 611.

Levenson, S. (1936). De la mobilité du Bacillus bifermentans. C.R. Soc. Biol., Paris, 121, 221.

Lillie, R. D. (1938). Pathologic histology in mice produced by intravenous inoculation with the toxin of Clostridium sordellii (bifermentans). Publ. Hlth Rep., Wash. 53, 113.

McCoy, E. \& McCuUng, L. S. (1986). Antigenic relations of Clostridium bifermentans and Clostridium centrosporogenes. J. Bact. 31, 557.

Macfarlane, M. G. (1948). The biochemistry of bacterial toxins. 3. The identification and immunological relations of lecithinases present in Clostridium oedematiens and Clostridium sordellii toxins. Biochem. J. 42, 590.

Macfarlane, R. G., Oakiey, C. L. \& Anderson, C. G. (1941). Haemolysis and the production of opalescence in serum and lecitho-vitellin by the $\alpha$ toxin of Clostridium welchii. J. Path. Bact. 52, 99.

Meisex, H. \& Rymkiewicz, D. (1958). Antigenic properties of spores of proteolytic clostridia. Abstracts, VII Int. Congr. Microbiol. p. 318.

Meleney, F. L., Humphreys, F. B. \& CARP, L. (1927). Pathogenic anaerobic bacillus not hitherto described cultured from fatal operative wound infection. Proc. Soc. exp. Biol., N.Y. 24, 675.

MiLes, E. M. \& MrLes, A. A. (1947). The lecithinase of Clostridium bifermentans and its relation to the $\alpha$-toxin of Clostridium welchii. J. gen. Microbiol. 1, 385.

OAKLEY, C. L. \& Warrack, G. H. (1941). Factors affecting the activity of the $\alpha$ toxin of Clostridium welchii. J. Path. Bact. 53, 335.

Oakley, C. L., Warrack, G. H. \& Clarke, P. H. (1947). The toxins of Clostridium oedematiens ( $\mathrm{Cl}$. novyi). J. gen. Microbiol. 1, 90.

Oakley, C. L., Warrack, G. H. \& van Heyningen, W. E. (1946) The collagenase (K toxin) of $C l$. welchii type A. J. Path. Bact. 58, 229.

Prévot, A.-R. (1938). Études de systématique bactérienne. IV. Critique de la conception actuelle du genre Clostridium. Ann. Inst. Pasteur, 61, 72.

Prévot, A.-R. (1955). Biologie des maladies dues aux anaérobies. Paris: Éditions Médicales Flammarion.

Prévot, A.-R. (1957). Manuel de Classification et de détermination des bactéries anaérobies, 3rd ed. p. 211. Paris: Masson et Cie.

Prévot, A.-R. \& Capponi, M. (1949). Recherches sur l'hémolysine de Cl. bifermentans. Ann. Inst. Pasteur, 77, 772.

Prévot, A.-R. \& Cordier, P. (1941). Recherches biochimiques comparées sur $\mathrm{Cl}$. bifermentans, $\mathrm{Cl}$. sordellii et $\mathrm{Cl}$. aerofoetidum. Ann. Inst. Pasteur, 67, 473. 
Prévot, A.-R. \& Malgras, J. (1950). Recherches sur l'hémolysine de $\mathrm{Cl}$. sordellii. Ann. Inst. Pasteur, 78, 133.

ReED, G. B. (1952). In Bacterial and Mycotic Infections of Man, 2nd ed. Ed. R. J. Dubos. Philadelphia, U.S.A.: J. B. Lippincott Co.

Roland, F., Bourbon, D. \& SzturM, S. (1947). Différenciation rapide des enterobactériacées sans action sur le lactose. Ann. Inst. Pasteur, 73, 914.

Smith, L. DS. (1955). Introduction to the Pathogenic Anaerobes. Chicago, U.S.A.: University of Chicago Press.

Sordelli, A. (1922). Un anaérobie agent de gangrène gazeuse. C.R. Soc. Biol., Paris, 87, 838.

Spray, R. S. (1936). Semi-solid media for cultivation and identification of the sporulating anaerobes. J. Bact. 32, 135.

Sterne, M. \& van Heyningen, W. E. (1958). In Bacterial and Mycotic Infections of Man, 3rd ed. Ed. R. J. Dubos. Philadelphia, U.S.A.: J. B. Lippincott Co.

STEWART, S. E. (1938). The titration of bifermentans antitoxin and the relationship between Clostridium bifermentans and Clostridium sordellii. J. Bact. 35, 13.

Tardieux, P. \& Nisman, B. (1952). Recherches biochimiques et immunologiques sur les fractions polyosidiques de $\mathrm{Cl}$. bifermentans et de Cl. sordellii. Ann. Inst. Pasteur, 82, 458.

Tataki, H. \& Huet, M. (1953). Valeur du test de l'urease pour la différenciation de Cl. sordellii et Cl. bifermentans. Ann. Inst. Pasteur, 84, 890.

Tissier, H. \& Martelly (1902). Recherches sur la putréfaction de la viande de boucherie. Ann. Inst. Pasteur, 16, 865.

Topley and Wilson's Principles of Bacteriology and Immunity (1955), 4th ed. p. 1012. Ed. Wilson, G. S. \& Miles, A. A. London: Edward Arnold and Co.

Weinberg, M. \& SÉguin, P. (1918). La gangrène gazeuse. Paris: Masson et Cie.

Worwod, A. J. \& Proom, H. (1950). Identification of characteristic extracellular ninhydrin-positive substances produced by some bacteria. J. gen. Microbiol. 4, 501.

\section{EXPLANATION OF PLATE}

Colonies of Clostridium sordellii and C. bifermentans on stiff horse-blood agar plates. A, C. sordellii (pathogenic); B, C. bifermentans; C, C. sordellii (non-pathogenic). (All $\times 6$.)

(Received 15 January 1959) 
Journal of General Microbiology, Vol. 21, No. 1
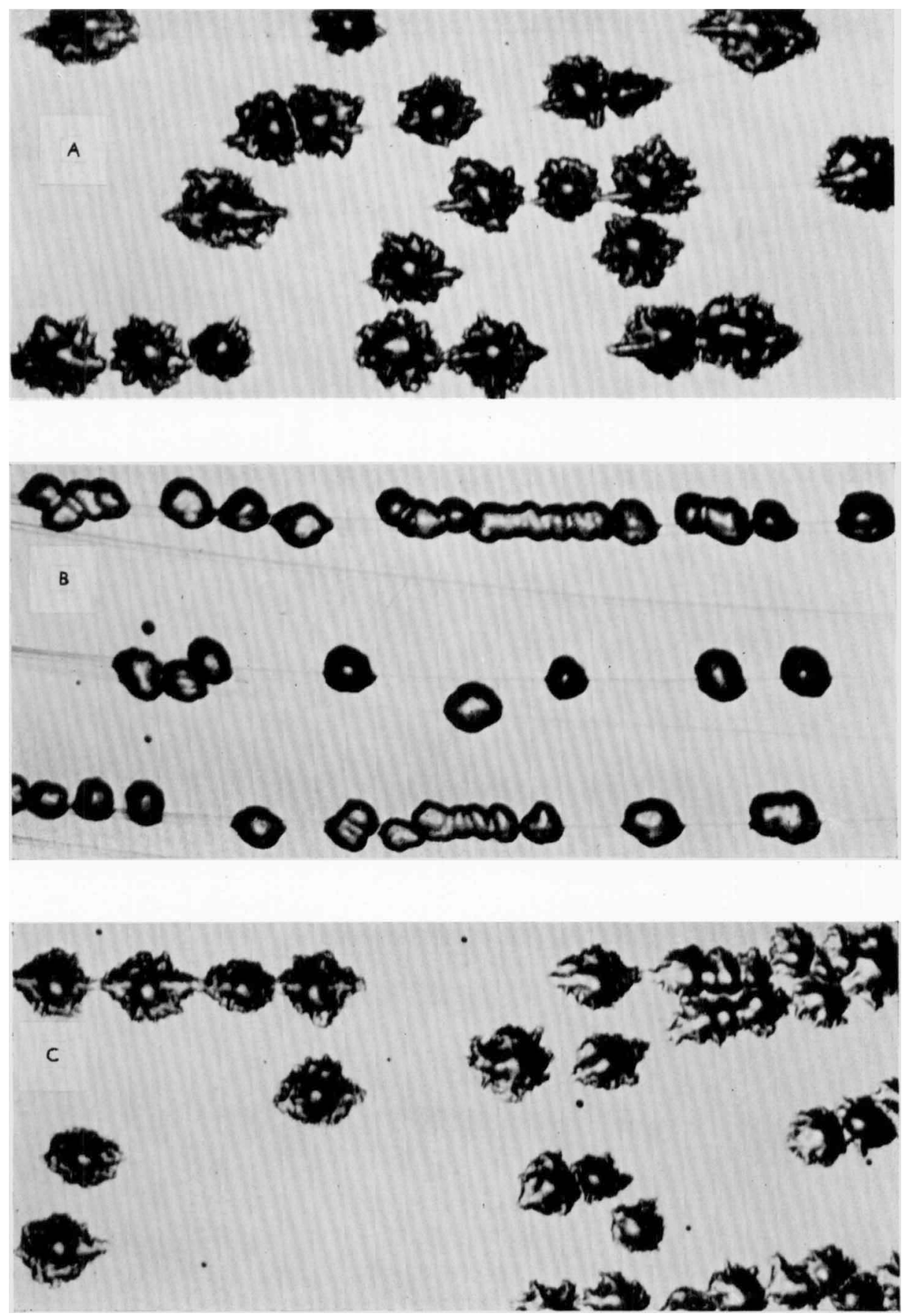

M. E. Brooks and H. B. G. Epps-The genus Clostridivm 